\title{
MIGRATION AND DISPERSAL OF AUDOUIN'S GULL LARUS AUDOUINII FROM THE EBRO DELTA COLONY
}

\author{
Daniel Oro ${ }^{1} \&$ Albert Martinez ${ }^{2}$ \\ ${ }^{1}$ Departament Biologia Animal, Vertebrats, Avda. Diagonal 645, 08028 Barcelona, Spain \\ ${ }^{2}$ Parc Natural del Delta de l'Ebre, Pça. 20 de Maig s/n 43580 Deltebre, Spain
}

\section{SUMMARY}

\begin{abstract}
Oro, D. \& MARTINEZ, A. 1994. Migration and dispersal of Audouin's Gull Larus audouinii from the Ebro Delta colony. Ostrich 65: 225-230.

Migratory paths and dispersal patterns of Audouin's Gulls (Larus audouinii) born in the Ebro Delta have been studied, as well as their degree of philopatry. The gulls always disperse southwards from the colony, and only the juveniles seem to disperse in other directions. Dispersal patterns of $2 y$, $3 y$ and older gulls are similar, wintering mainly on Iberian Mediterranean and Moroccan Atlantic coasts. Juveniles migrate before the rest of the age classes and they winter south of older gulls, in the Senegambia region. However, conclusions on Audouin's Gulls movements are difficult to draw, owing to the large differences in resighting and recovery efforts. Data presented also suggest that Audouin's Gulls do not appear to breed before the age of four years.
\end{abstract}

\section{INTRODUCTION}

Audouin's Gull (Larus audouinii) is one of the few endemic seabirds of the Mediterranean region. Just fifteen years ago its population was estimated to be only $600-800$ pairs (Witt 1977 a). Because of this, the species was included in lists of threatened European birds. Although its situation has improved recently, after the establishment of a new breeding colony in the Ebro Delta (NE Spain, Figure 1) in 1981 (Martinez \& Carrera 1983), the species endangered status has been maintained owing to its restricted distribution. Since 1981, the Ebro Delta colony has grown continuously and is now the largest in the world, with ca. 7000 pairs in 1992 (more than $60 \%$ of total world population) (Oro \& Martinez 1992). All the breeding colonies are located in the Mediterranean area, whereas the northwest African coasts seem to hold the main wintering quarters of the species.

Although Audouin's Gull is considered a dispersive or partially migratory species (Cramp \& Simmons 1983; Urban et al. 1986), little is known about the migration system of the species. Several studies deal with movements of the species through the Straits of Gibraltar (Cortés et al. 1980) or wintering far from the breeding colonies (Beaubrun 1983). Smith (1972) first recorded the regular wintering of Audouin's Gull along the north Atlantic coast of Africa. Lately, there has been an increase in seabird surveys along the West African coast, especially in Senegambia, with a consequent increase in records of Audouin's Gull (Baillon 1989; Mackrill 1989; Delaporte \& Dubois 1990; del Nevo et al. 1994). The ringing programme carried out at the Chafarinas Islands colony (SE Spain, Figure 1) since 1976 has provided further information on the migration movements of these gulls (De Juana et al. 1987), at least in relation to gulls born in this colony, which is the other main breeding nucleus of the species (De Juana et al. 1979).

The aim of this paper is to describe the migration of Audouin's Gulls from the Ebro Delta colony and how this changes with gull age.

\section{Study Area and Methods}

The Audouin's Gull colony at the Ebro Delta is located in a protected area formed by a sandy peninsula of 2000 ha (Punta de la Banya, $4037 \mathrm{~N}$ $0035 \mathrm{E}$ ). The peninsula is distinguished by a mosaic of salt marsh and small dunes covered by psammophilous vegetation (Camarasa et al. 1977).

Beginning in the 1981 breeding season, some chicks were ringed annually with individually numbered rings. Up to the 1992 breeding season, a total of 8853 chicks had been ringed. Since the 1988 breeding season, 3193 chicks were also ringed with a darvic ring with an alphanumeric code.

Although there was no constant effort in recoveries or resightings because of differences depending on place, country or time of year, we analysed ring recovery data up to the end of 1992, considering both resightings of darvic rings and recoveries of metal rings of birds found dead. Ages of birds corresponding to each recovery are given to the nearest year (birds recovered after 1 July were considered to belong to the next year age class). Four age classes were considered: $1 \mathrm{y}$ (juveniles or immatures in their first year of life), $2 y$ (sub-adults in their second year), 3y (sub-adults in their third year) and $4 y$ (adults in their fourth year and older).

\footnotetext{
Dispersal

To determine migration paths and levels of dispersal, the biases sometimes found with recoveries of ringed seabirds (Coulson \& Wooller 1976; Moller 1981) were taken into account. Thus, fledglings found dead at the breeding colony one year after ringing were usually not considered in the migration and dispersal analysis, except when reported as "freshly dead-within about a week". This avoids confusions in dating recoveries of fledgings which probably died during the past breeding season before fledging. Recoveries at breeding colony and at the Ebro Delta area have been also excluded.
}

Recovery records were grouped in six geo- 


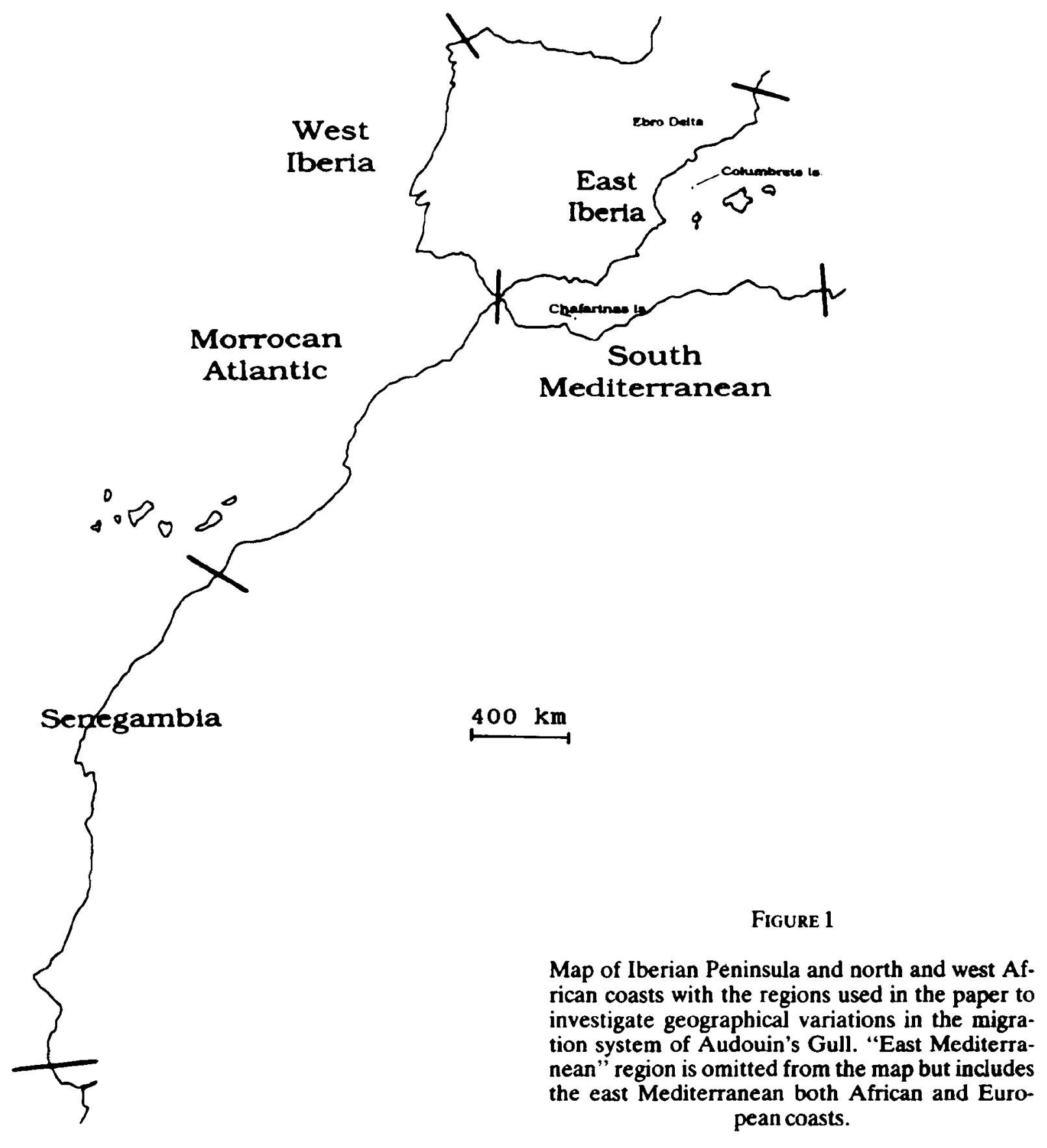

graphical regions and established applying the general criteria used by Klomp \& Furness (1992) to our particular case (Figure 1). Recoveries were also grouped in three sets of months: April to June (breeding season), July to October (postbreeding migration) and November to February (wintering and pre-breeding migration). We excluded recoveries in March because some gulls have already arrived at the breeding colony and these data could cause a strong bias.

Dispersal rates were analyzed by grouping recoveries according to successive $400 \mathrm{~km}$ zones (from the Ebro Delta colony). The percentages of gulls recovered at each zone, grouped by age classes, were plotted on a log scale against distance to show whether or not a constant proportion (dispersal rate $r$ ) of the gulls entering a zone remain within it. These dispersal rates $r$ and their standard deviations were calculated using procedures in Coulson \& Brazendale (1968) and Parsons \& Duncan (1978), which rely on a similar model for the calculation of average annual survival rates, but replacing age classes by distance classes.

Contingency tables and Chi-square tests were used as appropriate where statistical tests are needed. Kruskal-Wallis 1-way ANOVA and Mann-Whitney U' tests were also used.

\section{Results}

A total of 772 Audouin's Gulls ringed as chicks in the Ebro Delta since 1981 were recovered or resighted and reported up to the end of 1992 (Table 1). All the recoveries correspond to shoreline sites 
TABLE 1

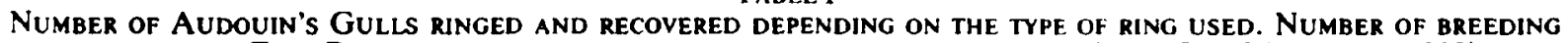
PAIRS IN THE Ebro Delta SINCE THE ESTABLISHMENT OF THE COLONY ARE SHOWN (FROM ORo \& MARTINEZ 1992)

\begin{tabular}{|c|c|c|c|c|c|}
\hline \multirow[b]{2}{*}{ Year } & \multirow[b]{2}{*}{ Breeding pairs } & \multicolumn{2}{|c|}{ No, of chicks ringed } & \multicolumn{2}{|c|}{ No. of birds recovered } \\
\hline & & Metal & Darvic & Metal & Darvic \\
\hline $\begin{array}{l}1981 \\
1983 \\
1985 \\
1986 \\
1987 \\
1988 \\
1989 \\
1990 \\
1991\end{array}$ & $\begin{array}{r}36 \\
200 \\
1200 \\
2200 \\
1850 \\
2860 \\
4270 \\
4300 \\
3950\end{array}$ & $\begin{array}{r}13 \\
106 \\
1572 \\
1858 \\
1626 \\
1053 \\
563 \\
769 \\
559\end{array}$ & $\begin{array}{r}0 \\
0 \\
0 \\
0 \\
0 \\
1040 \\
553 \\
399 \\
409\end{array}$ & $\begin{array}{r}0 \\
0 \\
18 \\
39 \\
16 \\
20 \\
14 \\
13 \\
4\end{array}$ & $\begin{array}{l}- \\
= \\
= \\
\overline{-} \\
135 \\
59 \\
23\end{array}$ \\
\hline Total & & 8119 & 2401 & 124 & 648 \\
\hline
\end{tabular}

or their surroundings, confirming that the gulls rarely move inland, although an exceptional inland sighting has been recorded (Urban et al. 1986).

\section{Dispersal}

Most of the recoveries during the breeding season were of $4 y$ gulls at the Ebro Delta, whilst the 2-3y gulls were recovered throughout the Iberian Mediterranean coastline, some of them in the region of the Ebro Delta (Table 2). Juveniles recovered during this season were mainly $(83,8 \%)$ away from the breeding colony, on the Atlantic (concentrated at the Doñana National Park coastline and surroundings) and Iberian Mediterranean coasts, whereas only $5,4 \%$ of them stayed on the African Atlantic coast.

After the breeding season, 2-3y and older gulls were recovered mainly at the $E$ and $S$ Iberian Peninsula coasts. During the winter season these gulls moved southwards, especially to the Atlantic coast of Morocco. Juveniles behaved differently, moving further south than $2-3 y$ and $4 y$ or older gulls, reaching the Senegambia coast in high percentages $(81,8 \%)$. Figure 2 and 3 show that there is no difference in the maximum distance dispersed for $2-3 y$ and older gulls either in their dispersal rates, whilst juveniles moved far away from the breeding colony in the winter peaks. Censuses performed in winter at the Mediterranean Iberian coasts also reported the absence of immatures in these areas (Robledano 1990) or low sighting rates (Hoogendoorn \& Mackrill 1987; Paterson 1987).

Numeric values of dispersal rates $(r)$ for age classes are given in Table 3 . All the figures reported are rather similar, although differences among age classes are significant (Kruskal-Wallis $\chi^{2}=29.46, p<0,0001$ ). Further comparisons between each pair of age classes were carried out using Mann-Whitney U tests with a Bonferroni correction to ensure an overall $\alpha<0,05$. All the comparisons showed significant differences between each pair of age class, except when comparing $4 y$ class with both $2 y$ and $3 y$ classes.

\section{Discussion}

Ring recovery data are subject to different biases, such as different sighting efforts depending on place, country or time of year, giving problems in the interpretation of ring recovery data (see review in North 1987). For example, in our case, $43,5 \%$ of darvic readings and $31,9 \%$ of metal recoveries were recorded at the Ebro Delta, and $50,5 \%$ of gulls were recovered during the breeding season. Moreover, some analyses, such as the calculation of dispersal rates, may emphasize the misinterpretation of the results because $r$ is a constant which is meant to express an average but does not provide information on the shape of the curve. Nevertheless, the use of this rate is forced by the lack of additional analytical and statistical works in dispersal studies. Conclusions on Audouin's Gulls movements are therefore difficult to interpret from available data.

However, large numbers of recoveries at the Ebro Delta provide information about the age classes of gulls returning to the breeding colony

TABLE 2

Percentages of recoveries of Audouin's Gull in each geographical region between 1985 and up to the end of 1992 IN RELATION TO DIFFERENT AGES AND TIME OF YEAR (SEE TEXT FOR EXPLANATIONS). THE EBRO DELTA REGION INCLUDES THE $100 \mathrm{KM}$ SURROUNDING THE BREEDING COLONY.

\begin{tabular}{|c|c|c|c|c|c|c|c|c|c|c|}
\hline $\begin{array}{l}\text { Region } \\
\text { Ebro Delta } \\
\text { East Iberia } \\
\text { West Iberia } \\
\text { SMediterranean } \\
\text { EMediterranean } \\
\text { Morocan Atlantic } \\
\text { Senegambia }\end{array}$ & $\underset{\%}{\text { Age }}$ & $\begin{array}{r}1 \\
(6,7) \\
27,1 \\
35,3 \\
27,1 \\
4,2 \\
2,1 \\
2,1 \\
2,1\end{array}$ & $\begin{array}{c}\text { Jul-Oct } \\
2-3 \\
(16,5) \\
3,4 \\
59,7 \\
33,6 \\
0,8 \\
0 \\
0 \\
2,5\end{array}$ & $\begin{array}{c}>4 \\
(10,4) \\
24,0 \\
50,7 \\
14,7 \\
6,7 \\
0 \\
1,2 \\
2,7\end{array}$ & $\begin{array}{c}1 \\
(1,6) \\
18,2 \\
0 \\
0 \\
0 \\
0 \\
0 \\
81,8\end{array}$ & $\begin{array}{c}\text { Nov-Feb } \\
2-3 \\
(5,6) \\
17,5 \\
27,5 \\
5,5 \\
17,5 \\
0 \\
27,5 \\
5,0\end{array}$ & $\begin{array}{c}>4 \\
(6,6) \\
44,7 \\
8,5 \\
0 \\
6,4 \\
0 \\
29,8 \\
10,6\end{array}$ & $\begin{array}{c}1 \\
(5,1) \\
10,8 \\
48,6 \\
35,2 \\
0 \\
0 \\
2.7 \\
2,7\end{array}$ & $\begin{array}{c}\text { Apr-Jun } \\
2-3 \\
(17,2) \\
37.9 \\
54,0 \\
6,5 \\
0,8 \\
0 \\
0,8 \\
0\end{array}$ & $\begin{array}{c}>4 \\
(30,3) \\
94,0 \\
5,5 \\
0 \\
0 \\
0 \\
0,5 \\
0\end{array}$ \\
\hline Total n & & 48 & 119 & 75 & 11 & 40 & 47 & 37 & 124 & 219 \\
\hline
\end{tabular}



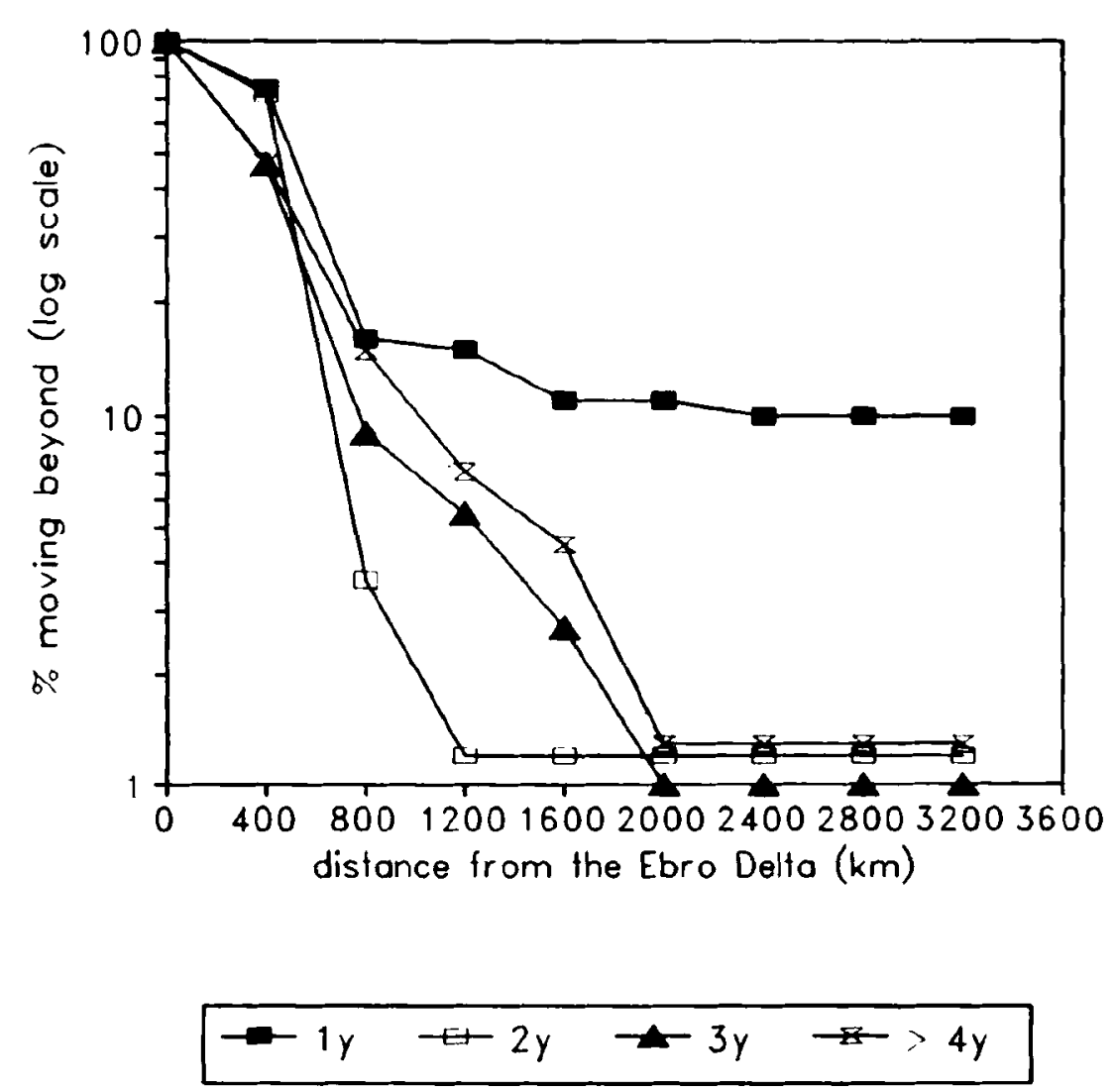

FIGURE 2

Percentage of Audouin's Gulls from each of four age classes moving beyond each $400 \mathrm{~km}$ distance from the Ebro Delta plotted on a logarithmic scale against distance. The data consist of all recoveries except those between April and June for $>4 y$ birds.

and about immigration rates from other colonies. During the 1992 season, we read 233 different darvic rings; of which, $76,8 \%$ were $4 y$ old $16,7 \% 3 y$ old, $5,1 \% 2 y$ old and $1,4 \%$ ly gulls. Moreover, only the older $4 y$ gulls were recovered mostly at the colony during the breeding season $(94,0 \%)$. Gulls do not commonly breed before the age of 4 , although some $3 y$ old gulls have been observed breeding at the colony (our observ.). These are the first data on the age of Audouin's Gulls at first breeding.

Our results of Audouin's Gulls movements coincided basically with those found by De Juana et al. (1987), but gulls from Chafarinas Is. rarely disperse to Iberian coasts, substantiating data from the Ebro Delta which did not show dispersal to the northern coasts either. Dispersal patterns of $2 y, 3 y$ and older gulls are similar, wintering mainly on Iberian Mediterranean and Moroccan Atlantic coasts.

Immatures sometimes displayed post-breeding dispersal in the "wrong" direction (one recovery in Albania $1600 \mathrm{~km}$ East; another recovery at Galicia, NW Spain, $850 \mathrm{~km}$ West). This postbreeding dispersal is similar to the Chafarinas Is. case, where juveniles migrate before older gulls (Beaubrun 1983; De Juana 1987). Juveniles win-
TABLE 3

VAlUES For DISPERSAL RATE $r$ POR DIFFERENT AGE CATEGORIES OF AUDOUIN'S GULL. THE DATA CONSIST OF ALL RECOVERIES EXCEPT THOSE BETWEEN ATRLL AND JUNE POR $>4 y$ BIRDS.

\begin{tabular}{lccc}
\hline Age & N & Dispersal rate & S.D. \\
\hline $1 y$ & 100 & 62,2 & 3,8 \\
$2 y$ & 166 & 56,4 & 2,9 \\
$3 y$ & 145 & 51,5 & 2,9 \\
$\geq 3 y$ & 154 & 53,5 & 3,0 \\
\hline
\end{tabular}

ter further south than older 2-3y gulls, in the Senegambia region. Once adults and sub-adults return to the breeding grounds, juveniles seem to move north, staying widely distributed along the Mediterranean Iberian coasts and the Doñana N.P. area. More studies will be needed to determine why juveniles and older gulls do not share the winterquarters at Senegambia, especially in view of the richness of this zone brought about by the upwelling (Brown 1979).

\section{ACKNOWLEDGMENTS}

We thank Grup Català d'Anellament (G.C.A.), specially E. Carrera, and participants on the ringing 


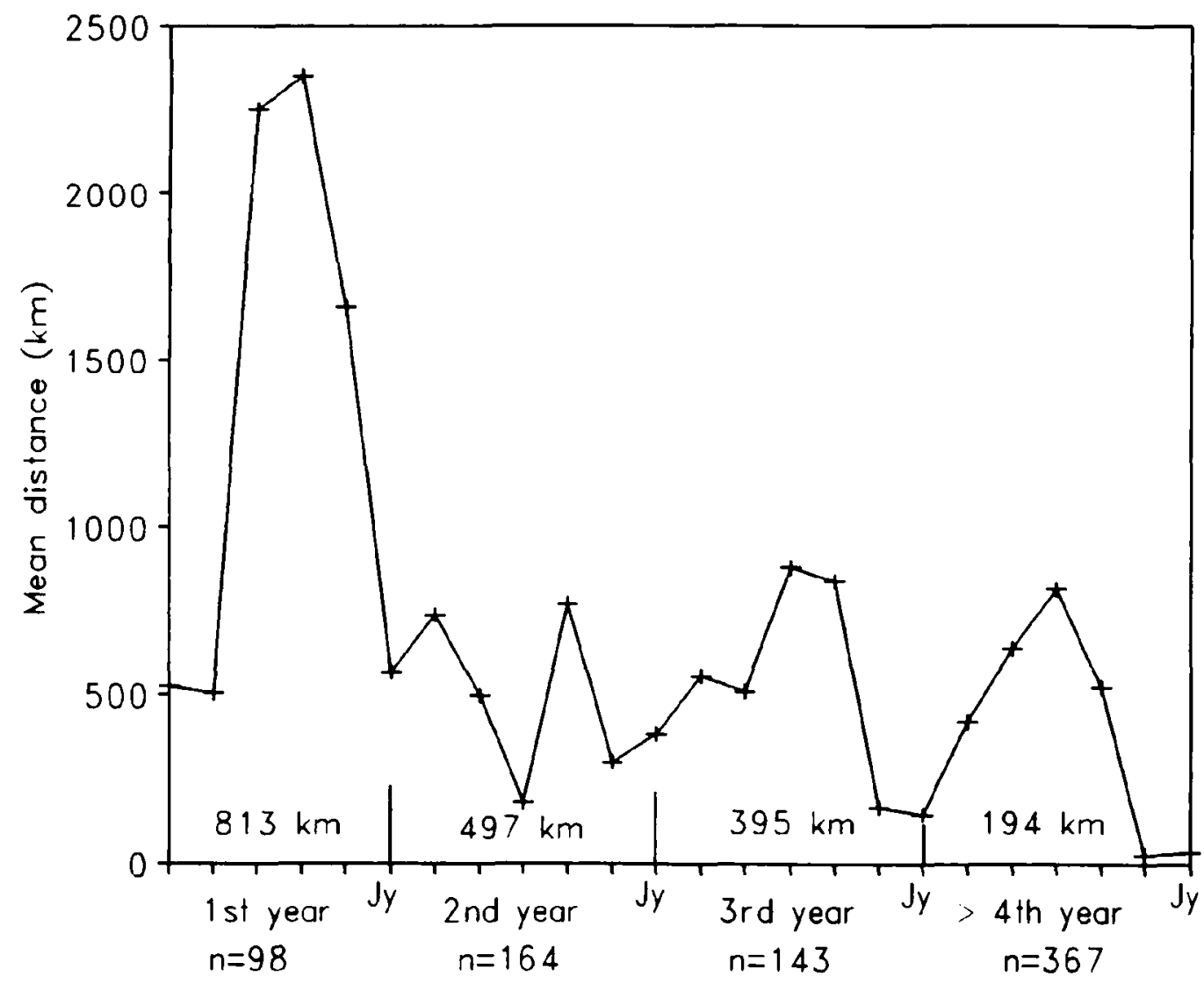

FIGURE 3

The mean distance moved by Audouin's Gull from the Ebro Delta according to month and age. Recoveries are grouped by set of two months to allow meaningful values ( $\mathrm{N}>5$ for all samples). Mean distance moved for each age class is shown in the graph.

journeys, as well as all the technicians and people in general who gave information about recoveries and readings of darvic rings. We wish also to thank $R$. Aymi, M. Genovart, and J. Piera for their help in different stages of this research. Drs. Ll. Jover, $X$. Ruiz, W.K. Steele and $W$. Suter provided helpful comments on this paper, and we are also grateful to Dr. T. Oatley for his encouragement. Research funds were provided by Parc Natural del Delta de l'Ebre and the DGICYT grant PB91-0271 of the Spanish Government.

\section{REFERENCES}

Barllon, F. 1989. Nouvelles donnés sur l'hivernage du Goelland d'Audouin Larus audouinii, Payr. en Senegambie. Oiseau Rev. Fr. Orn. 59: 296-304

Benubrun, P-C. 1983. Le Goéland d'Audouin (Larus audouinii Payr.) sur les côtes du Maroc. Oiseau rev. Fr. Orn. 53: 209-226.

Brown, R.G.B. 1979. Seabirds of the Senegal upwelling and adjacent waters. Ibis 121: 283-292.

Camarasa, J.M., Folch, R., Masalles, R.M. \& VeLAsCo, E. 1977. El paisatge vegetal del Delta de l'Ebre. Treb. Inst. Cat. Hist. Nat. 8: 47-67.

Cortes, J.E., Finlayson, J.C., Mosquera, M.A. \& GARCIA, E.F.J. 1980. The birds of Gibraltar. Gibraltar: Gibraltar Bookshop.

Coulson, J.C. \& Brazendale, MG 1968. Movements of Cormorants ringed in the British Isles and evidence of colony-specific dispersal. Brit. Birds 61: 1-21.

Coulson, J.C. \& Wooller, R.D. 1976. Differential survival rates among breeding Kittiwake gulls Rissa tridactyla (L.). J. Anim. Ecol. 45: 205-213.

Coulson, J.C. \& Butterfield, J. 1985. Movements of British Herring Gulls. Bird Study 32: 91-103.

Cramp, S. \& Simmons, K.E.L. (Eds.) 1983. The Birds of Western Paleartic, Vol. III. Oxford: Oxford University Press.

Delaporte, P. \& Dubois, P.J. 1990. Premier recensement hivernal des Larides súr les cótes du Senegal et de Gambie. Alauda 58: 163-172.

De Juana, E., Bueno, J.M., Carbonell, M., PerezMEllado V. \& VArela, J. 1979. Aspectos de la alimentación y biología de reproducción de Larus audouinii Payr. en su gran colonia de cria de las islas Chafarinas (año 1976). Bol. Est. Cent. de Ecol. 16: 53-66.

De Juana, E., Bradley, P., Varela, J. \& Witt, H. 1987. Sobre los movimientos migratorios de la Gaviota de Audouin (Larus audouinii). Ardeola 34: 1524.

Del Nevo, A.J., Rodwell, S., Sim, I.M.W., SaunDERS, C.R. \& WACHER, T. 1994. Audouin's gulls Larus audouinii in Senegambia. Seabird 16: 57-61

Hoogendoorn, W. \& Mackrill, E.J. 1987. Audouin's Gull in southwestern Palearctic. Dutch Bird. 9: 99. 107.

Klomp, N.I. \& Furness, R.W. 1992. The dispersal and philopatry of Great Skuas from Foula, Shetland. Ring. \& Mig. 13: 7382.

MaCkRILl, E.J. 1989. Audouin's Gulls in Senegal in January 1989. Dutch Bird. 11: 122-123.

Martinez, I. \& Carrera, E. 1983. Nova colonia de Gavina Corsa Larus audouinii Payr. a l'Estat Espanyol. But. Inst. Cat. d'Hist. Nat. 49: 159-161.

Moller, A. P. 1981. The migration of European Sand- 
wich Terns Sterna s. sandvicensis. Vogelwane 31: 74 94.

NorTH, P.M. 1987. Ring recovery analytical methods: A brief review. Acta Orn. 23: 7-12.

Oro, D. \& Martinez-Vilalta, A. 1992. The colony of the Audouin's Gull at the Ebro Delta. Avocetta 16: 36-39.

Parsons, J. \& Duncan, N. 1978. Recoveries and dispersal of Herring Gulls from the Isle of May. J. Anim. Ecol. 47: 993-1005.

Paterson, A.M. 1987. A study of seabirds in Malaga Bay, Spain. Ardeola 34: 167-192.

RoBleDANO, F. 1990. La invernada de Larus audouinii en la region de Murcia (SE, España). Ardeola 37: 90 . 93.
Ruiz, X., Oro, D., Martinez, A. \& Jover, L. (in press). Feeding ecology of Audouin's Gull (Larus audouinii) in the Ebro Delta. Col. Waterbirds.

SMITH, K.D. 1972. The winter distribution of Larus audouinii. Bull. Brit. Orn. Club 92: 34-37.

URBAN, E.K., FrY, C.H. \& KeITH, S. 1986. The birds of Africa. Vol. 2, pp: 361-362. London: Academic Press.

WITT, H-H. 1977a. Zur Verhaltensbiologie der Korallenmöwe Larus audouinii. Z. Tierpsychol. 43:46-47.

WrT, H-H. 1977b. Zur Biologie der Korallenmówe Larus audouinii- Brut und Ernāhrung. J. Orn. 118: 134 155. 